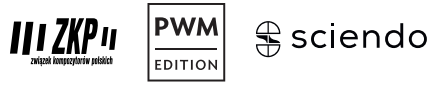

\section{National Icon and Cultural Ambassador: Zoltán Kodály in the Musical Life of State Socialist Hungary}

\begin{abstract}
LÓRÁN T PÉTERI
Musicology Department of the Liszt Academy of Music, Budapest, Hungary Uniwersytet Muzyczny im. Ferenca Liszta w Budapeszcie, Wydział Muzykologii 凶peteri.lorant@zeneakademia.hu
\end{abstract}

DOI: $10.2478 / \mathrm{prm}-2021-0011$

Based on archival sources, my paper analyses the political and professional position of composer, ethnomusicologist and musical educationalist Zoltán Kodály (1882-1967) in the Stalinist and post-Stalinist periods of Hungarian state socialism. His situation is not merely interesting owing to his being an outstanding figure in modern Hungarian cultural history, but also because of his ambition and capacity to exert influence in various fields: art, academia, education, and cultural politics.

During the interwar period, Kodály subordinated his compositions, his work as a professor of composition, his musicological research, and also his music pedagogical agenda to his complex program for the renewal of Hungarian music culture. This program was based on a personal ideology, which can be traced back to various aesthetic, historical, psychological, and sociological convictions or value judgements. ${ }^{1}$ The point of departure for

1 Kodály's collected writings were published in his Visszatekintés [Looking Back], 3 vols., ed. Ferenc Bónis (Budapest: Zenemükiadó, 1982, 1989). See especially his studies "Néprajz és zenetörténet" [Ethnography and Music History, 1933], in Visszatekintés II, 225-234; “Mi a magyar a zenében?" [What is Hungarian in Music?, 1939], in Visszatekintés I, 75-80;

Ikona narodowa i ambasador kultury wegierskiej: Zoltán Kodály w życiu muzycznym komunistycznych Wegier

(C) 2021 by Lóránt Péteri. - This is an open access article licensed under the Creative Commons Attribution-ShareAlike International (CC-BY-SA 4.o) 
his manifestos was often a critique of the state of affairs of Hungarian music culture described as socially fragmented, poor in terms of quality, and generally backward. According to Kodály, that situation resulted from the superficiality and the "alien" (that is Germanic) spirit of Hungarian Verbürgerlichung and urbanisation. Kodály believed that, in the long-drawn process of nation-building, Hungarian music culture was still in need of a (re-)integration whose foundation could only be found in autochthonous Hungarian folk music, labelled by Kodály as the Hungarian "musical mother tongue" 2 , even the "unique Hungarian classical music" 3 , which can be traced back to the "soul of the people of the Hungarian conquest" 4 . Folk music, in Kodály's view, had to penetrate music teaching in public education as well as the compositional style of new Hungarian music, along with all other aspects and phenomena of music culture. These ideas were accompanied by the conservative classicism of Kodály's aesthetics, his preference for the vocal genres, his Anglophile traditionalism, his reservations about the strong German orientation of Hungarian culture and politics, and the "psychologising-utopian" legitimation of his doctrine. ${ }^{5}$ From the $1930 \mathrm{~s}$ onwards, Kodály placed many of his pupils, young musicians and intellectuals, at the service of his teachings. They worked hard to meet Kodály's music cultural purposes in the fields of composition, music criticism, musicology, music education, choral culture, and music publishing. In one of his studies, Hungarian sociologist Miklós Hadas interpreted the Kodály phenomenon in the framework of the sociology of religion, labelling Kodály, his pupils, and his doctrine as "prophet," "sect," and "soteriology,"

and “Magyarság a zenében” [Hungarianness in Music, 1939], in Visszatekintés II, 235-260. Unless otherwise stated, all quotations transl. by the author.

2 Kodály, "Mi a magyar a zenében?," 77.

3 Kodály, "Magyarság a zenében," 259.

4 Ibidem, 247.

5 Miklós Hadas, “A nemzet prófétája: Kísérlet Kodály pályájának szociológiai értelmezésére" [The Prophet of the Nation: An Attempt at a Sociological Analysis of the Career of Kodály], Szociológia 1987, No. 4, 479. For Kodály's aesthetics and his compositional oeuvre generally, see Anna Dalos, Zoltán Kodály's World of Music (Berkeley and Los Angeles: University of California Press, 2020). 
respectively. ${ }^{6}$ The "sect" was an informal though centralised web of projects and personalities. Kodály's overall programme, however, had a clear ambition to exert influence on public policies. In the hope for partial success, Kodály seemed to have been ready to emphasise those elements of his programme that were most marketable in a certain cultural political regime. Owing to the frequent, radical political changes in mid- $2 \mathrm{O}^{\text {th }}$-century Hungary, Kodály re-tailored the communication of his music-cultural programme from time to time.

\section{The Second Republic and Stalinism $\left(1945^{-1956}\right)^{7}$}

Following a belated and failed attempt to extricate Hungary from the war, Miklós Horthy's nationalist authoritarian regime, which had governed the country between 1920 and 1944, collapsed, and Ferenc Szálasi, leader of the fascist-type Arrow Cross Party, was installed as the new prime minister and later as the "leader of the nation". Under Szálasi, Hungary continued her participation in the war as an ally of the Third Reich, whose troops, nonetheless, had occupied the country already in March 1944. After the Soviet Union's Red Army drove the Germans out from Hungary in the spring of 1945, a new political system was established in the country, and the republic as a form of government was declared in February 1946. The so-called Second Hungarian Republic can be characterised, initially, as a parliamentary democracy based on a slightly restricted political and cultural pluralism, and as a market economy on which the significance of public property and state regulation had a remarkable impact. In spite of limited support from the society, the Communist Party had a privileged position in, and dynamically growing control over the political system, as a result of the massive Soviet influence on the country. While the label

6 Hadas: “A nemzet prófétája," 469-490.

7 For this period, see also my study "The 'Question of Nationalism' in Hungarian Musicology during the State Socialist Period," in Nationality vs Universality: Music Historiographies in Central and Eastern Europe, ed. Sławomira Żerańska-Kominek (Newcastle upon Tyne: Cambridge Scholars Publishing, 2016), 125-144. 
"Second Republic" seems to suggest systemic stability, other descriptions, such as "Sovietisation" or "Pre-Stalinisation," emphasise the transitory nature of the epoch between the end of the War and the open communist takeover of $1948 .{ }^{8}$

That period witnessed the peak of the career of Zoltán Kodály as a public intellectual. After the emigration of composer, pianist, and conductor Ernő Dohnányi (November 1944), and the death of composer, pianist and ethnomusicologist Béla Bartók in the United States (September 1945), where he had emigrated in 1940, Zoltán Kodály turned into the number-one notable of Hungarian musical life. The grand old man of Hungarian folk music research enjoyed significant prestige even outside the field of music, well evidenced by the fact that he was not only the President of both the Hungarian Academy of Sciences and the Hungarian Council of Arts, but also a member of the National Assembly. ${ }^{9}$ Apart from his scholarly and artistic achievements, respect for him arose from the carefully critical political attitude he had assumed towards Horthy's regime. Together with Béla Bartók, Kodály was among the fifty-nine Hungarian intellectuals who signed a petition against the anti-Semitic legislation of the government in 1938, and openly rejected discrimination, embracing the values of equal civilian rights, social solidarity and Christian humanism. ${ }^{10}$ Furthermore, some of Kodály's writings on music and of his compositions from the late 1930 s and the early 1940 s can be interpreted as indirect criticisms of the tightening alliance between Hungary and the Third Reich. ${ }^{11}$ At the same time, Kodály's idea of a specific musical "Hungarian-ness”, and his search

8 For differing terminology, see György Gyarmati, A Rákosi-korszak: Rendszerváltó fordulatokévtizede Magyarországon, 1945-1956 [The Rákosi Era: A Decade of Systemic Changes in Hungary, 1945-1956] (Budapest: ÁB TL-Rubicon, 2011); Ignác Romsics, Magyarország története a XX. században [The $2 \mathrm{O}^{\text {th }}$-Century History of Hungary] (Budapest: Osiris, 1999); Ignác Romsics, A 20. század rövid története [A Brief History of the $2 \mathrm{O}^{\text {th }}$ Century] (Budapest: Rubicon, 2011).

9 Hadas, "A nemzet prófétája," 485.

10 János Gyurgyák, A zsidókérdés Magyarországon [The Jewish Question in Hungary] (Budapest: Osiris, 2001), 142.

11 Tibor Tallián, Magyar képek: Fejezetek a magyar zeneélet és zeneszerzés történetéből, 1940-1956 [Hungarian Pictures: Chapters of Hungarian Music Culture and Musical 
for "the unchanged foundation of the Hungarian soul" in folk music ${ }^{12}$ gained growing acclaim among the representatives of the cultural political power. In 1942, his $60^{\text {th }}$ birthday gave the government and various cultural institutions an excellent opportunity to demonstrate reverence for Kodály. In the same year, Kodály and his colleagues accepted a commission from the Ministry of Religion and Public Education to produce new schoolbooks, an anthology of songs, and methodology for music teaching at elementary schools. In 1943, Kodály was elected member of the Hungarian Academy of Sciences. ${ }^{13}$ Nonetheless, Kodály's frequently expressed solidarity with the Hungarian peasantry, his distancing himself from anti-Semitism and Nazi orientation, and his commitment to a democratic national culture elevated him to a central position in the Second Republic.

In the field of arts and culture, the open communist takeover of 1948 was accompanied by a political drive to replace the "old" elites (in the name of the ideological construct of "class struggle"), the import of the ongoing Soviet ideological campaign conducted by Andrey Aleksandrovich Zhdanov, and a radical reorganisation of funding and institutional frameworks. After the Soviet communist party's 1948 resolution on music, the overlaps between Kodály's aesthetics and that of the Zhdanovshchina became obvious. ${ }^{14}$ They consisted in their shared preference for folkloristic national classicism, for the vocal genres, and for the artistic role of "educator of the

Composition, 1940-1956] (Budapest: Balassi Kiadó, MTA Bölcsészettudományi Kutatóközpont, 2014), 102-107.

12 Kodály, "Mi a magyar a zenében?," 76.

13 Tallián, "Magyar képek", 23-27.

14 For an English translation of the resolution " On the Opera The Great Friendship by V. Muradeli', issued by the Central Committee of the Communist Party of the Soviet Union (Bolsheviks) on February 10 $0^{\text {th }}, 1948^{\prime}$, see Andrey Olkhovsky, Music under the Soviets: The Agony of an Art (New York: Praeger, 1955), 280-285. A Hungarian translation of the resolution was published in the daily of the Hungarian communist party and also in the Hungarian-language daily of the Soviet Red Army in February 1948: Szabad Nép, 17 February 1948; Új Szó, 19 February 1948. Selected writings of Andrey Aleksandrovich Zhdanov, the leader of the Soviet cultural campaign, which started in 1946, were also published in Hungarian: A.A. Zsdánov [Zhdanov], A müvészet és filozófia kérdéseiről [On Questions of Art and Philosophy] (Budapest: Szikra, 1949). 
people". Prominent people in Hungarian music culture reacted variously to the resolution, but most of them shared one conviction, namely, that Hungarian composers - building on the style of Bartók and Kodály - could not be "inimical to the people" in the sense some Soviet composers were accused of being. ${ }^{15}$ Kodály himself, however, soon came to be considered as an "enemy" from the point of view of Marxist-Leninist class struggle. A report made for the Cultural Policies Department of the Hungarian Workers' Party (the communist single party), in 1949, described Zoltán Kodály as follows:

His weakness lies in not recognising the great intensity of class struggle in Hungarian society and in not acknowledging the decisiveness of class conflict. What Kodály does is not opposing bourgeois society but, rather, expanding it in order to create the idyllic perspective of a [possible] bourgeois development for the Hungarian peasantry ${ }^{16}$.

As a result of the class-struggle perspective asserting itself in the country's cultural management, Kodály lost all his prominent positions. ${ }^{17}$ As early as in 1950, however, the communists' transformative drive started losing momentum. It seems the communist regime was simply not in a position to fully enforce the "Sovietisation" of music and musicology. They lacked the cadres necessary for carrying out such a transformation. ${ }^{18}$ Communist cultural policy makers must have realised that, under the

15 Lóránt Péteri, “'Soviet Music' in Hungary: Ilya Golovin Reaches Budapest,” in Socialist Realism and Music, eds. Mikulaš Bek, Geoffrey Chew, Petr Macek (Prague: KLP Koniasch Latin Press, 2004), 150-153. See also Danielle Fosler-Lussier, Music Divided: Bartók's Legacy in Cold War Culture (Berkeley and Los Angeles: University of California Press, 2007), 4-7.

16 “Jelentés a magyar zenei élet helyzetéről és javaslat a legsürgősebb teendőkről” [Report on the current affairs of musical life, and suggestion for the most urgent agenda], 1949. National Archives of Hungary, Records of the Cultural Policies Department of the Hungarian Workers' Party (MNL OL, M-KS-276-109-11). For the question of Bartók's reception in Stalinist Hungary, and in particular the debates concerning the "dark" side (decadent, formalist, bourgeois tendencies) of his music, see Fosler-Lussier, Music Divided, 16-27.

17 Hadas, "A nemzet prófétája," 485.

18 “Jelentés a magyar zenei élet helyzetéről és javaslat a legsürgősebb teendőkről” [Report on the current affairs of musical life, and suggestion for the most urgent agenda], 1949. Similar shortages were also characteristic of the Sovietisation process in Polish higher education, see John Connelly, Captive University: the Sovietization of East German, Czech, 
circumstances, it was impossible to marginalise such a towering personality of the field as Kodály. The high status and prestige he enjoyed in the country's musical community would not allow it. Starting in 1907 several generations of composers and musicians had been brought up by Kodály at the Liszt Academy of Music. ${ }^{19}$ It was feared, therefore, that, owing to his informal network, this distinguished personality would be able to exert more influence even upon communist musicians than the Party itself. ${ }^{20}$

Following the old political maxim "If you cannot beat them, befriend them!" in 1951 the political leaders of cultural life resorted to new tactics. Their aim now was to win Kodály and his disciple, the influential musicologist Bence Szabolcsi, professor of the Liszt Academy, over by finding a common cause with them. They looked upon them more and more as "fellow travellers" rather than enemies. ${ }^{21}$ In 1949 Kodály was elected honorary president of the Association of Hungarian Musicians, a new Soviet-type organisation established in the same year, and he held that position until his death. Szabolcsi was elected president proper of the same organization in 1951. Indeed, Kodály had by then for a long time preached for the unity of Hungarian composition based on a common cultural goal and on the folkloristic and national traditions. His essentialist, teleological and nationalistic vision of a "Hungarian School of Composition" 22 as well as his

and Polish Higher Education, 1945-1956 (Chapell Hill and London: The University of North California Press, 2000), 151.

19 László Eősze, Kodály Zoltán életének krónikája [The Chronicle of the Life of Zoltán Kodály] (Budapest: Editio Musica, 2007), 44. The institution, which had been founded in 1875, was renamed many times under the changing administrations of Hungarian higher education. Its current, official Hungarian name is Liszt Ferenc Zeneművészeti Egyetem, whose literal translation is Ferenc Liszt University of Music. In international communication, however, the institution still uses the name of the Liszt Academy of Music.

20 The crucial role of informal networks in Polish academia's resistance to the Stalinist replacement of its elites is emphasised in Connelly, Captive University, 144, 173.

21 The minutes of the meeting of the leadership of the communist aktiva of the Association of Hungarian Musicians, $9^{\text {th }}$ November 1950. National Archives of Hungary, Records of the Agitation and Propaganda Department of the Hungarian Workers' Party (MNL OL, M-Ks-276-89-384).

22 Anna Dalos, "It is not a Kodály School, but it is Hungarian," Hungarian Quarterly 48, No. 186 (2007), 146-159. 
pedagogical utopia of a "singing people" made his elevation into the top position appear as a plausible and effective move aiming at the centralisation of the country's musical life in the hands of the communist cultural-political establishment. Furthermore, in Hungarian composition the easiest way to satisfy the expectations of the political power, inspired by Zhdanov's aesthetics, was to follow the style of Kodály. ${ }^{23}$ The Zhdanov Doctrine privileged musical composition based on folkloristic and national traditions, which, in turn, propelled research into national and ethnic characteristics in music, undertaken in 1948-1956. Though heated debates took place over the question of whether the old or the new style of folk songs, or perhaps the $19^{\text {th }}$-century national popular style, was the one most compatible with socialist realist art, the acknowledgement of the unity of the folk-national tradition provided the debating partners with a common ground. ${ }^{24}$

It is important to see that the emerging cooperation-oriented relationship between Kodály, Szabolcsi, and the communist cultural-political management was built upon an emphasis on overlapping components of their respective aesthetic and intellectual agendas. Similarly, differences in viewpoints tended to be suppressed and kept beneath the surface. ${ }^{25}$ It seems a particular kind of deal had been struck between Kodály and Szabolcsi on the one hand and the communist leaders of the country's cultural life on the other. In exchange for their active presence in public (cultural) life, which legitimised the Stalinist cultural-political regime in Hungary, Kodály and Szabolcsi were given command over the infrastructure in a field that was regarded as being of relatively little consequence, namely

23 György Kroó, A magyar zeneszerzés harminc éve [30 years of Hungarian music] (Budapest: Zenemükiadó, 1975), 40-46.

24 See the minutes of the debates of the [First] Hungarian Music Week, $2 \mathrm{O}^{\text {th }}$ and $24^{\text {th }}$ November 1951. National Archives of Hungary, Records of the Association of Hungarian Musicians (MNL OL, P 2146/61).

25 Lóránt Péteri, "God and Revolution - Rewriting the Absolute: Bence Szabolcsi and the Discourse of Hungarian Musical Life," in Music's Intellectual History, ed. Zdravko Blažeković, Barbara Dobbs Mackenzie (New York: Repertoire International de Litterature Musicale, 2009), 337-342 (RILM Perspectives 1). 
musicology. ${ }^{26}$ In the environment of an academia reorganised in the Soviet manner, the foundation of the Committee of Musicology of the Hungarian Academy of Sciences was an act of recognition of musicology as a field of knowledge and scholarly research. ${ }^{27}$ The Committee started to function in 1951 under Kodály's presidency, which lasted till his death. The first and only institutional representation of the discipline in Hungarian higher education, the Department of Musicology, was also founded in 1951 at the Liszt Academy of Music. Its ethnomusicological program was initiated and led by Kodály, while Szabolcsi was among the founding professors and became head of department soon. In 1953 the Hungarian Academy of Sciences set up the Folk Music Research Group, again under Kodály's leadership. ${ }^{28}$

In these emerging new institutions Kodály and Szabolcsi not only assumed leadership but also gained relatively autonomous space for their professional and organisational activities. One of the important preconditions of asserting professional autonomy had been the emergence of an informal regime of hierarchical patron-client relations. Instead of leaving them to the apparatus of the party-state, József Révai, the number-one cultural political authority of the Stalinist regime, had a direct, personal relationship to the privileged representatives of the field. Révai was the patron, he represented the top of the three-level hierarchy; if the need arose, he protected Kodály and Szabolcsi against the recurring pressure in his apparatus to replace cultural elites. While Kodály and Szabolcsi were clients of Révai, they also acted as patrons in relation to their musicologist colleagues regarded as "reactionaries" by the commissars of the cultural sphere.

Similar deals, bargains, and compromises between the academic and the cultural political elite were also typical of Polish academia in the early 1950s, see Connelly, Captive University, 149-150.

27 “Az MTA Zenetudományi Szakbizottsága alakuló ülésének jegyzőkönyve” [Minutes of the inaugural meeting of the Committee of Musicology of the Hungarian Academy of Sciences], $4^{\text {th }}$ May 1951. Library and Information Centre of the Hungarian Academy of Sciences, Department of Manuscripts and Rare Books, Bequest of Bence Szabolcsi (MTA KKT: Ms 5637).

28 Imre Biacsi, "Notes for the Presidium of the Hungarian Academy of Sciences," $13^{\text {th }}$ February 1953. Archives of the Hungarian Academy of Sciences, Records of the President (MTA KLT: Elnök iratai 54/2/54). 
The former were no doubt dependent upon their protection, employment opportunities, and the publicity secured for them by Szabolcsi and Kodály. ${ }^{29}$

As part of the political changes following upon Stalin's death, Révai was removed from the Political Bureau of the Hungarian Workers' Party and from his position as Minister of Culture already in 1953. The cautious de-Stalinisation (the so-called "New Course") undertaken by the first government of Imre Nagy (1953-1955), however, did not result in any weakening of Kodály's position. On the contrary, Kodály's patriotism served as a point of crystallisation for those left-wing and reform-oriented communist intellectuals who urged a break with the Stalinist political practice and wished to make the Soviet Union's imposed control over the country less tight. After Mátyás Rákosi, the long-time leader of the Hungarian Workers' Party, made a resolute attempt at re-Stalinisation of the political, economic and social spheres in the spring of 1955, Kodály expressed his repugnance in various symbolic gestures. In June 1956, together with about fifty other cultural and political celebrities, Kodály joined the birthday party of the reformist communist statesman Imre Nagy, the former prime minister forced out by Rákosi. ${ }^{30}$ In terms of style, genre, and choice of lyrics, Kodály's Zrínyi szózata [Hymn of Zrínyi] for baritone solo and mixed choir, 1955, and his Nemzeti dal [National Song] for male choir, 1956, remained in line with Zhdanovian expectations, and were welcomed by the party-state controlled press. In spite of that, Kodály's settings of a text by $17^{\text {th }}$-century statesman, military leader, and poet Miklós Zrínyi, and of a poem by $19^{\text {th }}$-century Romantic Sándor Petőfi were interpreted by many members of the audience as manifestations of the demand for the restoration of

29 For documents of the interpersonal relations, see József Révai's letter to Bence Szabolcsi, 10 July 1952; and musicologist Antal Molnár's letter to Bence Szabolcsi, 4 August 1960. Library and Information Centre of the Hungarian Academy of Sciences, Department of Manuscripts and Rare Books, Bequest of Bence Szabolcsi (MTA K KT: Ms. 5641/137. and Ms. 5640/372). For the significance of patronage in the Soviet music culture of the $1930 \mathrm{~s}$ and 1940s, see Kiril Tomoff, “'Most Respected Comrade...': Patrons, Clients, Brokers and Unofficial Networks in the Stalinist Music World," Contemporary European History 11/1 (February 2002), 33-66.

30 Romsics, Magyarország története a Xx. században, 382 . 
national sovereignty. ${ }^{31}$ It seems therefore, that a discourse in which "national" elements appeared as a relevant, differentiating characteristic of contemporary cultural phenomena was actively maintained by both Stalinists and anti-Stalinists, which explains why Kodály's image as a national icon was reinforced in the early 1950 .

\section{Revolution, State Socialist Restoration, and Consolidation (1956-1962)}

Social and political tensions as well as the news on the Polish October led on $23^{\text {rd }}$ October to the outbreak of Hungary's anti-Stalinist revolution, and to Imre Nagy's coming back to the leadership of the government on the following day. Kodály spent the autumn and winter of 1956 at a hilly holiday destination in Hungary and thus did not take any active part in the revolution. In spite of that, participants of the revolution bestowed direct political legitimacy on Kodály. On $13^{\text {th }}$ November 1956, the Petöfi Party (the strongest democratic party), re-organised during the revolution, issued a proposal to set up a National Governing Council. According to the proposal the Council would serve as a collective head of state. Nominated to become president of the Council was Zoltán Kodály, who was later elected, in absentia, president of the Revolutionary Council of Hungarian Intellectuals, founded on 21st November 1956.32

After the suppression of the revolution, the Soviets installed János Kádár as the new leader of the reorganised and renamed communist party, now called the Hungarian Socialist Workers' Party. One of the crucial lines of action in the consolidation period of Kádár's regime, that is, between 1956 and 1963, was state Socialist restoration and post-revolutionary retaliation. At the same time, Kádár was quick to conclude that social and

31 János Breuer, Kodály-kalauz [A Guide to Kodály] (Budapest: Zeneműkiadó, 1982), 327; Mihály Ittzés, “Zrínyi szózata: Ötven éve mutatták be Kodály Zoltán kórusművét” [The Hymn of Zrínyi. Zoltán Kodály's Choral Work was Premiered Fifty Years Ago], Forrás 37/12 (December 2005), 73-75.

32 Éva Standeisky, Az irók és a hatalom, 1956-1963 [Writers and the Political Power] (Budapest: 1956-os Intézet, 1996), 127, 144-145. 
political explosion - as a response to classical Stalinist political practice could happen again. Consequently, the consolidation period involved corrective measures alongside the restoration. These measures did not only result from the worrying experiences of the revolution. The Sixties were "the longest, most successful correction-and-reform period of the Hungarian version of the Soviet-type system, and even of the Eastern Bloc, which made a truly lasting impression on the political system" 33 .

Retaliation after the 1956 revolution, the restitution of state-socialist dictatorship, and the specific characteristics of Kádár's system, different from Stalinist practice, exerted a crucial impact on Kodály's situation in four areas. (1) The retaliation chiefly affected Kodály through some of his clients. The side-lining and political harassment of his close colleagues tested the efficiency of Kodály's informal network. As emphasised by historian György Péteri, the "phenomena of purge [...] and patronage tended to go hand in hand: indeed, purges created the very typical situation within which personal patronage (protection) was in dire demand" 34 . (2) However, in 1958 the cultural policy of the Kádár regime openly broke with the idea of a socialist culture led in one privileged direction. Consequently, competing cultural and aesthetic paradigms appeared on the musical scene, naturally within the framework determined by the political power. This presented a new challenge to Kodály's teachings. Kodály's position was weakened by two factors: firstly, the late arrival of Hungarian musical modernism in the late 1950 os and early 1960 , and, secondly, the breakthrough caused by popular music and musical mass culture. ${ }^{35}$ (3) After the suppression of the anti-Stalinist revolution of 1956, whose representatives often applied the rhetoric of national independence, the re-established state-socialist cultural

33 János Rainer M., Bevezetés a kádárizmusba [An Introduction to Kádárism] (Budapest: 1956-os Intézet and L'Harmattan, 2011), 159.

34 György Péteri, “Purge and Patronage: Kádár's Counter-Revolution and the Field of Economic Research in Hungary, 1957-1958," Contemporary European History 11/1 (February 2002), 125-152.

35 For evaluation of these tendencies, see Kroó, A magyar zeneszerzés harminc éve, 93-125; Tibor Tallián, Magyarországi hangversenyélet 1945-1958 [Concert Culture in Hungary, 1945-1958] (Budapest: MTA Zenetudományi Intézet, 1991), 117-119. 
administration became more cautious about references to "national" values and traditions. The so-called "revolutionary" or "progressive" nationalism encouraged by high Stalinism was no longer desirable, as was clearly demonstrated in the 1959 theses of the Hungarian Socialist Workers' Party titled "On bourgeois nationalism and socialist patriotism." (4) However, Kodály had a side to him which the political power considered particularly valuable, and which strengthened his position on the musical scene; namely, the maestro's considerable international fame and relationship capital, which, in comparison with his Hungarian contemporaries, was unparalleled. The Stalinist regime did not put this reputation to use between 1949 and 1956, because it was little concerned with its standing in the West. However, for Kádár's government, which advocated a foreign policy of "peaceful coexistence" and which sought to achieve international legitimacy, the cultural-diplomatic capital that came with Kodály's travels and relationships was extremely important.

On $1^{\text {st }}$ September 1959, Zoltán Kodály addressed János Kádár in a personal letter. He was interceding with the political leader of Hungary for the music teacher Irma Bors and the composer and folk-music researcher Pál Járdányi. ${ }^{36}$ In terms of content, the letter belongs to the genre of requests bypassing the official decision-making process. In his reply of $15^{\text {th }}$ October 1959, Kádár presented Kodály with a complex letter four times as long. Kádár very tactfully and in a rhetorically creative way presented Kodály his image of the maestro's role. Kádár expressed a thought that was, perhaps, not entirely self-evident. The politician was at that time ruling the country mostly relying on power-enforcement organisations and with a legitimacy that even many communist groups called into question. He was indicating that he acknowledged Kodály's legitimacy based on respect and consensus. At the climax of his letter, he considers as theoretically equal the plan which stemmed from the Communist calling of elevating the Hungarian people and the plan which had evolved from Kodály's educational concept. He wrote to Kodály:

Published in Kedves, jó Kádár elvtárs! Válogatás Kádár János levelezéséből 1954-1989 [Dear Good Comrade Kádár: Selected Correspondence of János Kádár 1954-1989], ed. Tibor Huszár (Budapest: Osiris, 2002), 141. 
It cannot be denied that you love the people and that your work in musical culture has been a great and important contribution to our people. Our people is your people, but it is also mine, and I'm a communist.

At the end of the letter Kádár proceeded to put the record straight and establish the hierarchy he believed to be evident, saying:

Owing to my position, I am more aware than you of the extent and the way in which we and our entire people are stumbling on the Socialist path of our new life ${ }^{37}$.

In 1957, Kodály received his third Kossuth Prize. ${ }^{38}$ He remained honorary president at the helm of the Association of Hungarian Musicians and was a board member of the National Council of the Patriotic People's Front. ${ }^{39}$ In 1957, the Ministry of Culture continued the long tradition of celebrating Kodály's birthday. In addition to the usual four events held in celebration of his birthdays (a concert of youth choirs, a concert of self-taught amateur choirs, a performance of Kodály's singspiel, Háry János (1926) at the State Opera House, and a concert given by the Hungarian State Orchestra), two additional chamber music evenings and a further orchestral concert were hosted by the National Philharmonic. Also, in conjunction with the $75^{\text {th }}$ birthday, the State Folk Ensemble performed his play Székely fonó [Spinnery: A Scene from Transylvanian Village Life] (1932), and there were several concerts and talks given in local towns. ${ }^{40} \mathrm{On}$ his birthday,

37 Ibidem, 144.

38 A highly prestigious, state-sponsored award which was established in 1948, always presented at the Parliament to acknowledge outstanding achievements in the fields of culture, arts, and science.

39 The key objective of this organisation was to mediate the goals of the single party to the people, and to win supporters from outside the party for these goals, see Romsics, Magyarország története $a x x$. században, 409. The flow of information and opinions was not, however, entirely unilateral in the organisation. Political leaders of the country also used the People's Front for consultation purposes. They tested the social reception of their proposed measures in, among other places, this organisation, which compensated for the lack of real political competition and plurality.

40 Árpád Fasang to György Aczél, 19 November 1957. National Archives of Hungary, Records of György Aczél (MNL OL, XIX-I-4-aaa-49-52). 
Kodály received a letter from deputy minister of culture György Aczél, as did Mrs Kodály in the same year. ${ }^{41}$

However, simultaneously with the public gestures of the cultural political leadership that approached Kodály, and the initiatives to "involve and initiate" ${ }^{42}$ Kodály into the political system, an action plan was drawn up in the Ministry of Culture as early as in 1959 which sought to marginalise Kodály. It can therefore be inferred that the various leaders at different levels of cultural policies could come to different conclusions regarding the correct path to follow. What is certain is that Mrs András Barna, head of the music and dance department of the Ministry of Culture, proved to be Kodály's active enemy with a keen political sense. She was the first policymaker to become aware of the fact that the emerging stylistic diversity of Hungarian musical composition would necessarily change the symbolic status of Kodály in musical life. Kodály naturally remained the doyen of Hungarian composers; however, as the idea of folk-music inspiring the national language of composition gradually became obsolete, Kodály's presence in musical life was sometimes regarded as uncomfortable. A new generation of Hungarian composers came to the fore, which drew on its belated compositional experience of Western modernism of the 1920s and 1930s in new works composed around 1960. The cultural political leadership did not wish to bring administrative measures to curtail these new phenomena. Instead, it created an ideological framework that made them interpretable as integral parts of Hungary's socialist culture. As early as in 1957 the cultural political doctrine acknowledged a "competition of trends" and, alongside the rule of "socialist realism" it decided to support other "realist trends" as well. In the meantime, it tolerated the "non-realist trends" that "presented no threat to the people's democracy" 43 .

György Aczél to Mr and Mrs Zoltán Kodály [1957-1958]. National Archives of Hungary, Records of György Aczél (MNL OL, XIX-I-4-aaa- 49-52; MNL OL, XIX-I-4-aaa-56-81). Melinda Kalmár, Ennivaló és hozomány: A kora kádárizmus ideológiája [Food and Dowry: The Ideology of Early Kádárism] (Budapest: Magvető, 1998), 151.

43 "Questions of Arts Policy," [14 December?] 1957. National Archives of Hungary, Records of the Science and Culture Department of the Central Committee of the Hungarian Socialist Workers' Party (MNL OL, M-KS-288-33/1957/1). 
Although, in 1959 Mrs Barna still considered "modernist" composers to be a threat, she very soon became aware that their presence changed Kodály's position on the musical-cultural scene and market of aesthetic paradigms: "Kodály and his closest ally, [Pál] Járdányi, no longer hold sway over the young composers anymore, because those latter consider their ideas to be conservative" 44 . She therefore decided the moment had come to isolate Kodály also in the areas where he still held considerable influence, primarily in musicology. She branded the Folk Music Research Group at the Hungarian Academy of Sciences, headed by Kodály, as reactionary and unscientific and, in relation to some of its staff members, as clerical and nationalistic. Until 1962 Kodály would have been uncertain as to whether his scholarly workshop could retain its autonomy. 45

However, all efforts aimed at merging the Group with others and taking away research positions had proved vain by 1962 . Kodály had therefore won a battle. To be precise, the political power gave up fighting this battle in the first place. It would have been a big mistake in any case to confront Kodály over an area of so little importance at the social level. Kodály's public appearances in Western cultural centres did good service to a Hungary that wished to comply with the global politics based on the peaceful coexistence of the "capitalist" and "socialist" systems.

However, recognising this good service did not mean that his travels could not be used to test the relations between Kodály and the political apparatus, at least until 1962. Prior to his trip to England in 1960, Kodály had to face a conformist attitude on the part of the cadres of the party-state. Negotiating with a Ministry representative and a Soviet diplomat, Zoltán Kodály complained that György Aczél and István Szirmai, secretary of the Party's Central Committee, tried to prevent Mrs Kodály from travelling to England, for fear that the elderly composer and his young second wife

44 Mrs András Barna, "Általános helyzetkép a mai magyar zeneélet egyes területeiről," [Overview of some territories of present-day Hungarian music life], 10 August 1959. National Archives of Hungary, Records of the Science and Culture Department of the Central Committee of the Hungarian Socialist Workers' Party (MNL OL, M-KS-288-33/1959/8).

45 A detailed survey of the situation of the Folk Music Research Group around 1960 can be found in Péteri, “The 'Question of Nationalism'," 136-138. 
would be grist to the mill of the English press and wished to protect the maestro from this hassle (Kodály was 78 , his wife was 20 then). All the same Kodály, alluding to the fact that he was soon to be awarded an honorary doctorate of the University of Oxford, explained that he "merely wished to travel to England for the sake of the young woman. He wished to present himself to his wife wearing the robe of an honorary doctor and the square academic cap, which he could now take home". Very possibly, of course, cultural leadership prohibited Mrs Kodály from travelling out of fear that Kodály might decide to emigrate. ${ }^{46}$ On later occasions, both Kodály and his wife were allowed to travel to England, a decision that proved appropriate, as confirmed by a report from the Hungarian Embassy in London:

We believe that allowing Kodály's wife to travel was the right decision. Although many are taken aback by the age difference, we at least managed to avoid all the guesswork associated with her staying at home ${ }^{47}$.

In return for his passive and active contributions to the legitimation of the political system, Kodály expected reciprocity from the political leadership in two areas: people under his patronage and the professional field of music education.

Today Kodály promotes not himself, but his cadres. [...] [I]t should be made clear to him that his person does not require protection; however, we have no wish to pass on our respect, admiration, and tolerance to his unworthy followers.

Mrs Barna was not quite accurate in her observations. ${ }^{48}$ Kodály exploited his informal links to political leaders not only to promote his followers, but also to support people who came to him for help through mediators.

Vilmos Meruk to György Aczél, 28 April 196o. National Archives of Hungary, Classified Records of György Aczél (MNL OL, XIX-I-4-rrrr-2-958/A-1960).

47 Károly Szarka to György Aczél, 25 October 196o. National Archives of Hungary, Classified Records of György Aczél (MNL OL, XIX-I-4-rrrr- 2-2420/A-1960).

48 Mrs András Barna, "Általános helyzetkép a mai magyar zeneélet egyes területeiről" [Overview of some territories of present-day Hungarian music life], 10 August 1959. National Archives of Hungary, Records of the Science and Culture Department of the Central Committee of the Hungarian Socialist Workers' Party (MNL OL, M-KS-288-33/1959/8). 
One such person was Imre Mécs, a young electrical engineer sentenced to death for his revolutionary activities in 1956, for whom Kodály interceded with Gyula Kállai, communist politician and president of the National Council of the Patriotic People's Front. ${ }^{49}$

In the summer of 1959, the Ministry of Culture decided that Pál Járdányi, among other people, would be removed from his professorship at the Liszt Academy of Music. ${ }^{50}$ An admirer and, as a composer, a follower of Kodály, as well as his colleague in the Folk Music Research Group, Járdányi had been active in organisations of musicians and intellectuals involved in the 1956 revolution. He consistently and admirably maintained his political standing - chiefly his solidarity for the imprisoned writer Tibor Déry even during the period of retaliations. ${ }^{51}$ Zoltán Kodály not only approached ministry officials on behalf of Járdányi, but, as I have already mentioned, addressed János Kádár himself. In spite of lengthy correspondence, he was unable to save Járdányi's position at the Liszt Academy of Music.

In the same period Kodály interceded on behalf of Irma Bors, a former private student of his, who had been branded as "clerical" and removed from her post as vice-director of a prestigious primary music school in Budapest for political reasons. Kodály wrote to deputy minister of culture, Pál Ilku:

You are surely familiar with the primary music school in Lorántffy Street. It has been run for five years and owes the worldwide fame it has achieved in such a short span of time, as well as the admiration of foreign teachers, to Ms Irma Bors, the soul and heart of the institution and role model to her colleagues. [...] I have recently learned that she was moved to a non-music primary school in the $14^{\text {th }}$ district. This is like mowing with a razor-blade ${ }^{52}$.

49 János Breuer, Kodály és kora [Kodály and his Era] (Kecskemét: Kodály Intézet, 2002), 246. Mécs was released from prison in 1963. After the collapse of state socialism, in 1990, he was elected member of the Hungarian parliament.

50 Mrs Sándor Varga, "Nyugdíjazásra javasolt tanárok a művészetoktatási intézményekben” [Proposal for retirements at institutions of artistic education], 23 July 1958. National Archives of Hungary, Records of György Aczél (MNL OL, XIX-I-4-aaa-59-100).

51 Vilmos Meruk to Zoltán Kodály, 4 September 1959. National Archives of Hungary, Classified Records of György Aczél (MNL OL, XIX-I-4-rrr-1660/A-1959).

52 Zoltán Kodály to Pál Ilku, 3 August 1959. National Archives of Hungary, Records of Pál Ilku (MNL OL, XIX-I-4-Zs-85O-1959). 
Due to Kodály's vehement protest, the other deputy minister, György Aczél was forced to express his opinion ${ }^{53}$, and eventually also the leader of the country, János Kádár, personally admitted that removing the widely-known music teacher Irma Bors had been a mistake. He informed Kodály that as a compensation his protégée would be entrusted with the task of setting up a new music class at her current workplace. ${ }^{54}$

Kodály used private correspondence to intercede on behalf of Pál Járdányi and Irma Bors. However, on questions of music education, from the 1960 s onwards he entered more and more openly into conflicts with the regime, which found its reflection in the public sphere. The regime was at a loss how to deal with the elderly Kodály's activity. Kodály rightly felt that the regime essentially ignored his principles in its primary and secondary school policies. In use from 1963 till the early 1980 s, the ubiquitous primary-school music textbook taught children more mass songs of the Communist movement and fewer folk songs than at any time during the Stalinist fifties. ${ }^{55}$ In spite of the relatively large amount of time dedicated to solmisation and the portraits of Kodály hanging on the walls of the classrooms, this meant a renunciation of Kodály's educational and humanist principles. Some elements of the educational reforms which took shape from 1961 onwards affected music and betrayed the intention of the political power to indoctrinate the children. On the other hand, it is also clear that in the field of music pedagogy concepts different from Kodály's method were also gaining currency. In 1961 Kodály not only disapproved of reducing the number of music classes, but also asserted the claim that the minimal precondition for musical experience was the confident reading of music. At the same time, he was distrustful about the possibility of using children's instruments and expressed doubts concerning the idea of listening to recorded music in class, as suggested in the proposed curriculum. ${ }^{56}$

György Aczél to János Kádár, 12 September 1959. National Archives of Hungary, Classified Records of György Aczél (MNL OL, XIX-I-4-rrr-2-1660/A).

54 János Kádár to Zoltán Kodály, $15^{\text {th }}$ October 1959. Published in Kedves, jó Kádár elvtárs!, 142.

55 Hadas, "A nemzet prófétája," 483-484.

56 Zoltán Kodály's journal article "Megjegyzések az új tantervhez" [Commentaries on the new school curriculum"] was originally published in the journal of the Association of Hungarian 
The fact that at the age of eighty Kodály gave a speech in front of the Association of Hungarian Musicians is symbolic, because he had almost never taken the opportunity to speak up for this community before. The key point of his speech was the ongoing educational reform, and in particular the criticism of the proposed changes in primary-school music teaching. Kodály presented his arguments in the context of a conservative assessment of the general tendencies in musical life. The "ship" of Hungarian music, he said, was being drilled by three "sawfish," namely "jazz", "the radio," and "educational policy". While he believed the radio's programming policy lacked the presence of a normative element and an educational attitude, he condemned the psychological effects of what he referred to as "jazz". 57 Kodály spoke of jazz in general, yet he could hardly have meant the modern trends of the late 1950 s and the 6os. It would seem that his words referred to the popular big-band swing style of the thirties, as well as the experience of the sixties' Hungarian dance music. Nevertheless, in telling contrast to Kodály's anti-jazz outbursts, in 1965 a jazz department was set up at the Bartók Conservatory following the end of the anti-American witch-hunts.

Kodály's proposals to improve the musical-cultural situation embarrassingly evoked the spirit of collectivism, activism, and normative idealism from the Stalinist period in Hungary's public discourse on music that was only just beginning to build its pragmatism and pluralism. In 1962 he spoke about the Association of Musicians, asking:

What could be the purpose of an Association? To provide a ground for good music, to break 'fresh ground' and acknowledge the fact that there is still much left to do. It does not help the community if everyone cultivates their own 'backyard garden.' I have recently heard a talk on the radio that explained that the individuals benefited more if they cared more for the common land than for their own backyard, because if their attention focuses on the latter, the common land will be overgrown with weeds. The Association truly does have work to do in every area of musical life 58 .

Musicians, Magyar Zene 1, No. 6 (1961), 583-587, and was republished in Kodály, Visszatekintés I, 328-333.

57 Zoltán Kodály's lecture at the Association of Hungarian Musicians on $8^{\text {th }}$ March 1962. National Archives of Hungary, Records of Pál Ilku (MNL OL, XIX-I-4-Zs-917-1962-20). Published in print in Kodály, Visszatekintés III, 99-112.

58 Ibidem. 
Kodály's other important and recurrent point of reference was the Soviet example. In 1962, he presented to his colleagues the sense of responsibility evident in Soviet musical-pedagogical debates. Secondly, he drew attention to the apparent open-mindedness of Khrushchevism:

\footnotetext{
Khrushchev started conspicuously to applaud when [Alexander Trifonovich] Tvardovsky said that the party could not only be served by echoing the declarations of party headquarters, but also by coming up with new ideas. I'm not sure if the Hungarian government and party headquarters share the idea that led Khrushchev to applaud ${ }^{59}$.
}

Between 1948 and 1956 Kodály had been known to make such references to the Soviet Union, only in those years he was more rarely alone in this than after the 1956 revolution. In public musical discourse after 1956 even the representatives of the political power would employ the rhetoric of citing the Soviet Union as an example only as an embarrassing obligation. ${ }^{60}$

One striking characteristic of Kodály's argumentation was his defiant, defensive tone. In his speech, he frequently referred to his own "old-style" and "solitary hoeing" efforts. That cannot be regarded as a mere rhetorical device. Discussing his principles and long-term objectives in 1962, he was bringing back phantoms by referring to the superiority of the Soviet Union and the idea of collectivism in musical life. This meant that he had become uncertain about who the genuine allies supporting his programme were. Respected though he was, he must have felt estranged in the midst of Hungarian musical life in 1962.

\section{In the Consolidated Kádár Regime (1963-1967)}

As it has been pointed out, by 1963 a new order had emerged in primary and secondary school education, which, while evoking Kodály's pedagogy in certain technical aspects, on the whole meant the renouncement of Kodály's concept of culture. Understandably, therefore, Kodály focused

59 Ibidem.

60 Tallián, Magyarországi hangversenyélet, 117. 
on the specific model institution that was supposed to embody his cultural ideas, that is, the primary music school, where children had, in addition to the usual curriculum of primary schools, a higher number of music classes, were involved in choral singing, and often learnt to play instruments. ${ }^{61}$ However, from the late 1950 s onwards another type of institution had gradually developed into a national network, also with the objective of educating children and young people in music: the extra-curricular state music school. The focus of education in the state music schools was instrumental training and collective music-making (that is, orchestral and chamber music). Nevertheless, they embraced the methods sanctioned by Kodály in the area of musical ear development and reading and writing music. Considered as abstract ideals, the two institutions undeniably represented two different concepts of culture. The idea behind the primary music schools was Kodály's concept of the "singing people." The state music school was out to promote the values of "bourgeois" elite culture, making them available across the society - even if that could not be openly asserted in the 1960s. This had been the basic cultural-political tenet of the moderate social democrats at the turn of the century. Kodály was fairly hostile to the state music schools, which he considered as unwanted rivals to the primary music schools. He sought to pull strings through his informal network to obtain support from the political power. In 1966, he argued before Prime Minister Gyula Kállai, saying that the state music schools

\footnotetext{
fail to take into consideration the cultural, moral and economic significance of standard education [...] they jealously plot against the primary music schools [...] the state music schools embrace the old ideal of bourgeois music teaching, which professes that music belongs to the privileged classes [...] the state music school trains professional musicians ${ }^{62}$.
}

The Prime Minister invited Cultural Minister Pál Ilku to comment. Ilku defended the state music schools, pointing out that the two types of schools

61 Hadas, "A nemzet prófétája", 484.

62 Kodály is quoted by Pál Ilku, in his letter to Gyula Kállai, 16 November 1966. National Archives of Hungary, Records of Pál Ilku (MNL OL XIX-I-4-zs-2068-1966). 
served different, but mutually complementary functions, and both were schools of "music education for the masses" 63 .

The so-called "Kodály method" and the system of primary music schools were nevertheless cultural merchandise, whose diplomatic value was clear to the cultural policy makers of the sixties. ${ }^{64}$ Keen Western - particularly British and American - interest caused some confusion in the political circles. Decisions had to be made how and which institution would organise, supervise or even limit the activities of the delegations arriving in Hungary. ${ }^{65}$ This was a challenge that the political establishment had not faced in the fifties. In the mid-196os in the United States it was encouraged at the highest level that American experts in pedagogy should study the "Kodály method," American music teachers should be trained, and the Kodály pedagogy introduced in the United States. Kodály's visit to the United States in 1965 reinforced that initiative, as also did the support of violinist Isaac Stern, advisor to President Johnson. Hungarian decision-makers from the ministry of foreign affairs cautiously applauded the American proposal: "Should the proposed programme be accomplished, it would not only be Kodály's personal scholarly achievement, but recognition of Hungarian musical-educational methods on the whole" ${ }^{66}$. It should be noted that promotion of Kodály's pedagogy assumed important political dimensions also for the United States. Announced in 1964, President Johnson's policy of East-West "bridge building" acknowledged the existence of the Soviet bloc as a reality, and sought to normalise relations with the Kádár regime, which had mercilessly suppressed the revolution, but made significant efforts at consolidation. Simultaneously with the keen us interest in Kodály's pedagogy, diplomatic talks were under way, leading to an upgrade in relations between the two countries to ambassadorial rank in November

63 Ibidem.

64 For Kodály's pedagogical ideas, see his Writings on Music Education, ed. Mihály Itzzés, transl. Kata Ittzés (Budapest: Liszt Academy, 2019).

65 Report by Mrs András Barna, 22 August 1966. National Archives of Hungary, Declassified Records of the Ministry of Culture (MNL OL, XIX-I-4-VV-9-0022-77-1966).

66 Frigyes Vadász to Róbert Boros, 4 August 1966. National Archives of Hungary, Declassified Records of the Ministry of Culture (MNL OL, XIX-I-4-VV-9-0022-77-1966). 
1966. To gain support for this policy, Johnson's administration would hail Kodály, a humanist of international stature, as Kádárian Hungary's cultural ambassador to the United States. 67

Kodály's trip to Moscow in 1963 was a curious and (bizarre as it was) typical intermezzo in the relationship between the maestro and the cultural politicians of the state-socialist regime. In the spring of 1963 , the communist composer Tibor Sárai, general secretary of the Association of Hungarian Musicians, reported to Minister of Culture Pál Ilku the embarrassing fact that Zoltán Kodály's invitation to the Soviet Union would be postponed "for four or five years" ${ }^{68}$. Kodály had been ready to travel in the autumn of 1960, requesting that his trip should be connected with the first performance of one of his works in that country (for example Háry János or the oratorio Psalmus Hungaricus, 1923). ${ }^{69}$ Later he set two conditions only: that he should not be required to travel in the winter, owing to his old age, and that the visit should be linked with some other event, such as a scholarly talk he would give or the first performance of a work of his in the Soviet Union. The Soviet party promised to give Háry János its Soviet première in the 1961/1962 season in Leningrad. However, it transpired at the end of the season that the première was postponed.

In the meantime, honouring an insignificant proportion of his invitations to the West, Kodály began his visits to capitalist countries. The awarding of the honorary doctorate by the University of Oxford came in this period, as well as the première of the Symphony [1961] in several countries, a performance of Psalmus

67 As another notable example of musical "interface between East and West" during the Cold War, one might think of the Warsaw Autumn festivals; see Adrian Thomas, Polish Music since Szymanowski (Cambridge: Cambridge University Press, 2005), 83-91, quotation on p. 91. Further discussions of the "strong osmotic tendencies that were globalizing knowledge across the systemic divide about culture" can be found in the studies included in Nylon Curtain: Transnational and Transsystemic Tendencies in the Cultural Life of State-Socialist Russia and East-Central Europe, ed. György Péteri (Trondheim: Program on East European Cultures and Societies, 2006), quotation from György Péteri: "Introduction," 4.

68 Tibor Sárai to Pál Ilku, 10 April 1963. National Archives of Hungary, Records of Pál Ilku (MNL OL, XIX-I-4-Zs-1197-1963).

69 Vilmos Meruk to György Aczél, 28 April 1960. 


\begin{abstract}
Hungaricus at the Salzburger Festspiele in a programme also including Beethoven's Ninth Symphony, etc. As you, Comrade Ilku, will undoubtedly know, in countries where Kodály appears he is received by the heads of state and prime ministers, and as you are also surely aware that he staunchly represents Socialist Hungary at such events,
\end{abstract}

wrote Tibor Sárai, describing the embarrassing asymmetry of the situation. ${ }^{70}$ In the event, the Stanislavsky and Nemirovich-Danchenko Academic Music Theatre in Moscow took on the première of Háry János and a date was set for April 1963. Sárai reported that

three people from the Stanislavsky Theatre visited Kodály in the winter to discuss the details. The Old Man agreed to scores of changes, even musical ones, he was so curious about the reception of Háry in the Soviet Union ${ }^{71}$.

However, in the meantime it was again decided in Moscow that the performance would be postponed, because, so they claimed, they were dissatisfied with the Russian translation of the libretto. Once more Tibor Sárai was given the unrewarding task of breaking the news to Kodály. The Soviets did invite him to a performance of Psalmus, but Kodály declined it on the grounds that "he was interested in Háry" 72.

Finally, the date of Háry's Soviet première was set for December 1963. In spite of Kodály's wishes, the event took place in winter; nonetheless, it created an opportunity for the notables of the Soviet musical and cultural scene to celebrate the maestro's birthday. In conjunctions with Kodály's visit, the secretariat of the Union of Soviet Composers invited representatives of its Hungarian counterpart. Kodály attended the entire three-day meeting of the two musical associations, dealing with the musical output of their respective countries. He was elected honorary professor of Moscow Conservatoire; a gala dinner was given in honour of his birthday by the Soviet Minister of Culture and the Union of Soviet Composers; he met the Hungarian ambassador to Moscow, who held a reception for Kodály;

70 Tibor Sárai to Pál Ilku, 10 April 1963.

71 Ibidem.

72 Ibidem. 
he had a composer's night in the concert hall of the Conservatoire; and eventually, on $21^{\text {st }}$ December, he was able to attend the first Soviet performance of Háry. In his report, losing his pragmatism, Sárai opined that Kodály's speeches, statements and toasts,

would cover an important part of Hungarian music history. Kodály has never been this close to us [to the representatives of the state-socialist cultural political apparatus] as in the speeches he gave in the Soviet Union.

He went on to support this claim with half a dozen of quotes from Kodály. Kodály's bons mots partly praised the Hungarian regime, and partly highlighted the similarities between the Kodályian musical-cultural programme and the Soviet model. At the same time, Sárai established that throughout the conference debate on the interpretation of "folkloristic character," Kodály's presence was "awkward." Sárai reported that "Kodály kept joking us that "the Soviets agree with me, not with you" 73 .

Albeit with Kodály's approval, Háry János was tendentiously rearranged. The singspiel was announced as a comic opera, but the way in which it was presented in Moscow gave cause to comparing it to a classical grand operetta. The Russian text changed the basic atmosphere of the piece, as suggested by the anonymous informer from the Hungarian embassy in Moscow in his informative but dilletantish opera review intended for internal use:

Generally speaking the performance radiated joy and merriness, in the belief that this adequately expressed the Hungarian folk character; yet the grief over the fate of Hungarians, which is perhaps the main message of the original singspiel, did not come through in a straightforward and perceptible manner ${ }^{74}$.

Be that as it may, a representative of the Ministry of Culture considered the première of Háry and its reception to be a cultural-diplomatic victory:

We believe that the [local première of the] work was a significant event of Moscow cultural life, and will have a positive effect on broadening the cultural connections

Tibor Sárai to György Aczél, 27 December 1963. National Archives of Hungary, Records of the Association of Hungarian Musicians (MNL OL, P 2146/72). 
between the two countries. It is no accident that following the première, the Kirov Theatre in Leningrad, the Moscow Operetta, and the Stanislavsky Theatres showed considerable interest in Hungarian works ${ }^{75}$.

Likewise, Kodály's appearances in the Soviet Union was greatly valued by the Hungarian cultural political administration. Deputy cultural minister György Aczél made inquiries, and double-checked the information received from Tibor Sárai. Aczél's final conclusion was that Kodály had been "clearly positive throughout." Soviet cultural minister Yekaterina Furtseva reported to him how the maestro had discussed the Hungarian situation, stressing how

he profoundly trusted today's [political] leadership, and [...] felt that the country and the people were on the right track, and believed that his musical-pedagogical oeuvre was in the best hands ${ }^{76}$.

Aczél also reported that, on his return, Kodály had said to writer Gyula Illyés and others, "we have much to learn from the Soviet Union." Kodály had also apparently often jokingly said,

if it comes to the worst, and he cannot prove his rights to his colleagues at home, there is a place for him in the Soviet Union ${ }^{77}$.

The highly affirmative statements regarding the Hungarian political system presumably conveyed the message that, following a build-up of tensions in 1962, Kodály sought to consolidate his relationship with the regime that he still believed to be the possible means to achieving his cultural and educational objectives. Naturally, Kodály had little reason to make critical remarks about the Kádár regime in Moscow of all places and in 1963, during the general amnesty and in the climate of thaw after the harshest retaliation in Hungary. It remains an open question whether the representatives of the political power did not overestimate the role that the visit played in

75 Mrs Sándor Keleti to Béla Némethy, $31^{\text {st }}$ January 1964. National Archives of Hungary, Declassified Records of the Ministry Of Culture (MNL OL, XIX-I-4-VV-8-0010-1-1964).

76 Report by György Aczél, $2^{\text {nd }}$ March 1964 . National Archives of Hungary, Records of the Secretariat of János Kádár (MNL OL, M-KS-288-47-735).

77 Ibidem. 
legitimising the Hungarian political system at home. This is suggested by the fact that the Hungarian Association of Musicians had great trouble putting together the Moscow delegation. Outstanding representatives of the Hungarian musical elite declined the obligation to visit Moscow. ${ }^{78}$ Hungarian public musical sphere was at a loss, and indeed had no wish to deal with references to the Soviet model.

It cannot be doubted that the performance of Kodály's stage work - or at least its Russian-language version - for the Moscow audience was crucial to Kodály's self-esteem as a composer. He was well aware of the values of Russian musical culture, and he would have seen Moscow not only as the centre of the Soviet bloc, but also as an old, magnificent European cultural centre. Equally important to him would have been the sense of comfort derived from the fact that, unlike his Hungarian colleagues who pragmatically accepted the emergence of musical modernism and gave up on the utopia of a folk-based musical culture, Soviet communist cultural politicians presented themselves as allies because of their conservative and nationalist aesthetic views.

The fact that the post-1956 cultural policies gave up the idea of a unified Hungarian art which is "national in form and socialist in content," resulted in a temporary weakening of Kodály's position. Kodály's status was precarious, subjected to a challenge by avant-garde trends in composition, competing paradigms of musical education, and by new waves of popular music. Instead of introducing Kodály's principles in public education at large, his music-pedagogical ideas were tested in one specific type of primary school. As a patron, he remained active after the revolution, and, while successfully protecting the scholarly community of his Folk Music Research Group, he had to experience painful failures too. From the early 1960s, however, when both the Western and Eastern political systems proposed strategies for long-term coexistence, Kodály and his music pedagogy gained a new function from the perspective of the political power. In Western cultural circles, Kodály sustained a reputation as one of the great European humanists. During the last years of his life, Kodály seems to have functioned as a mediator across the global political divide, and this, finally, reinforced his position in Hungary. 


\section{BIBLIOGRAPHY/BIBLIOGRAFIA}

\section{Sources (chronologically) / Źródła (chronologicznie)}

Szabad Nép, 17 February 1948.

Új Szó, 19 February 1948.

“Jelentés a magyar zenei élet helyzetéről és javaslat a legsürgősebb teendőkről” [Report on the current affairs of musical life, and suggestion for the most urgent agenda], 1949. National Archives of Hungary, Records of the Cultural Policies Department of the Hungarian Workers' Party (MNL OL, M-KS-276-109-11).

Minutes of the meeting of the leadership of the communist aktiva of the Association of Hungarian Musicians, $9^{\text {th }}$ November 1950. National Archives of Hungary, Records of the Agitation and Propaganda Department of the Hungarian Workers' Party (MNL OL, M-KS-276-89-384).

"Az MTA Zenetudományi Szakbizottsága alakuló ülésének jegyzőkönyve" [Minutes of the inaugural meeting of the Committee of Musicology of the Hungarian Academy of Sciences], 4 May 1951. Library and Information Centre of the Hungarian Academy of Sciences, Department of Manuscripts and Rare Books, Bequest of Bence Szabolcsi (MTA KKT: Ms 5637).

Minutes of the debates of the [First] Hungarian Music Week, $2 \mathrm{O}^{\text {th }}$ and $24^{\text {th }}$ November 1951. National Archives of Hungary, Records of the Association of Hungarian Musicians (MNL OL, P 2146/61).

József Révai's letter to Bence Szabolcsi, 10 July 1952; Library and Information Centre of the Hungarian Academy of Sciences, Department of Manuscripts and Rare Books, Bequest of Bence Szabolcsi (MTA KKT: Ms. 5641/137. and Ms. 5640/372).

Imre Biacsi, "Notes for the Presidium of the Hungarian Academy of Sciences," 13 February 1953. Archives of the Hungarian Academy of Sciences, Records of the President (MTA KLT: Elnök iratai 54/2/54).

Árpád Fasang to György Aczél, 19 November 1957. National Archives of Hungary, Records of György Aczél (MNL OL, XIX-I-4-aaa-49-52).

"Questions of Arts Policy," [14 ${ }^{\text {th }}$ December?] 1957. National Archives of Hungary, Records of the Science and Culture Department of the Central Committee of the Hungarian Socialist Workers' Party (MNL OL, M-KS-288-33/1957/1).

György Aczél to Mr and Mrs Zoltán Kodály [1957-1958]. National Archives of Hungary, Records of György Aczél (MNL OL, XIX-I-4-aaa- 49-52; MNL OL, XIX-I-4-aaa-56-81). 
Mrs Sándor Varga, "Nyugdíjazásra javasolt tanárok a művészetoktatási intézményekben” [Proposal for retirements at institutions of artistic education], 23 $3^{\text {rd }}$ July 1958. National Archives of Hungary, Records of György Aczél (MNL OL, XIX-I-4-aaa-59-100).

Zoltán Kodály to Pál Ilku, 3 August 1959. National Archives of Hungary, Records of Pál Ilku (MNL OL, XIX-I-4-Zs-85O-1959).

Mrs András Barna, "Általános helyzetkép a mai magyar zeneélet egyes területeiről” [Overview of some territories of present-day Hungarian music life], 10 August 1959. National Archives of Hungary, Records of the Science and Culture Department of the Central Committee of the Hungarian Socialist Workers' Party (MNL OL, M-KS-288-33/1959/8).

Vilmos Meruk to Zoltán Kodály, 4 September 1959. National Archives of Hungary, Classified Records of György Aczél (MNL OL, XIX-I-4-rrr-1660/A-1959).

György Aczél to János Kádár, 12 September 1959. National Archives of Hungary, Classified Records of György Aczél (MNL OL, XIX-I-4-rrr-2-1660/A).

János Kádár to Zoltán Kodály, 15 October 1959. Published in Kedves, jó Kádár elvtárs!, 142.

Vilmos Meruk to György Aczél, 28 April 1960. National Archives of Hungary, Classified Records of György Aczél (MNL OL, XIX-I-4-rrrr-2-958/A-1960).

Antal Molnár's letter to Bence Szabolcsi, 4 August 1960; Library and Information Centre of the Hungarian Academy of Sciences, Department of Manuscripts and Rare Books, Bequest of Bence Szabolcsi (MTA KKT: Ms. 5641/137. and Ms. 5640/372).

Károly Szarka to György Aczél, 25 October 196o. National Archives of Hungary, Classified Records of György Aczél (MNL OL, XIX-I-4-rrrr- 2-2420/A-1960).

Zoltán Kodály's lecture at the Association of Hungarian Musicians on $8^{\text {th }}$ March 1962. National Archives of Hungary, Records of Pál Ilku (MNL OL, XIX-I-4-Zs-917-1962-20). Published in print in Kodály, Visszatekintés, III.

Tibor Sárai to Pál Ilku, 10 April 1963. National Archives of Hungary, Records of Pál Ilku (MNL OL XIX-I-4-Zs-1197-1963).

Tibor Sárai to György Aczél, 27 December 1963. National Archives of Hungary, Records of the Association of Hungarian Musicians (MNL OL, P 2146/72).

Report from the Moscow Embassy of Hungary, 9 January 1964. National Archives of Hungary, Declassified Records of the Ministry Of Culture (MNL OL, XIX-I-4-vv-8-0010-1-1964).

Mrs Sándor Keleti to Béla Némethy, 31 January 1964. National Archives of Hungary, Declassified Records of the Ministry Of Culture (MNL OL, XIX-I-4-vv-8-001O-1-1964).

György Aczél's Report, 2 March 1964. National Archives of Hungary, Records of the Secretariat of János Kádár (MNL OL, M-KS-288-47-735). 
Frigyes Vadász to Róbert Boros, 4 August 1966. National Archives of Hungary, Declassified Records of the Ministry of Culture (MNL OL, XIX-I-4-Vv-9-0022-77-1966).

Mrs András Barna's Report, 22 August 1966. National Archives of Hungary, Declassified Records of the Ministry of Culture (MNL OL, XIX-I-4-VV-9-0022-77-1966).

Pál Ilku to Gyula Kállai, 16 November 1966. National Archives of Hungary, Records of Pál Ilku (MNL OL XIX-I-4-Zs-2068-1966).

\section{Literature / Literatura}

János Breuer, Kodály és kora [Kodály and his Era]. Kecskemét: Kodály Intézet, 2002. János Breuer, Kodály-kalauz [A Guide to Kodály]. Budapest: Zeneműkiadó, 1982. John Connelly, Captive University: the Sovietization of East German, Czech, and Polish Higher Education, 1945-1956. Chapell Hill and London: The University of North California Press, 2000. Anna Dalos, "It is not a Kodály School, but it is Hungarian.” Hungarian Quarterly 48, no. 186 (2007).

Anna Dalos, Zoltán Kodály's World of Music. Berkeley and Los Angeles: University of California Press, 2020.

László Eősze, Kodály Zoltán életének krónikája [A Chronicle of the Life of Zoltán Kodály]. Budapest: Editio Musica, 2007.

Danielle Fosler-Lussier, Music Divided: Bartók's Legacy in Cold War Culture. Berkeley and Los Angeles: University of California Press, 2007.

György Gyarmati, A Rákosi-korszak: Rendszerváltó fordulatok évtizede Magyarországon, 19451956 [The Rákosi Era: A Decade of Systemic Changes in Hungary, 1945-1956]. Budapest: ÁBTL-Rubicon, 2011.

János Gyurgyák, A zsidókérdés Magyarországon [The Jewish Question in Hungary]. Budapest: Osiris, 2001.

Miklós Hadas,“A nemzet prófétája: Kísérlet Kodály pályájának szociológiai értelmezésére” [The Prophet of the Nation: An Attempt at a Sociological Analysis of the Career of Kodály]. Szociológia 1987, No. 4, 479.

Mihály Ittzés, “Zrínyi szózata: Ötven éve mutatták be Kodály Zoltán kórusművét” [The Hymn of Zrínyi. Zoltán Kodály's Choral Work Was Premiered Fifty Years Ago]. Forrás 37/12 (December 2005).

Melinda Kalmár, Ennivaló és hozomány: A kora kádárizmus ideológiája [Food and Dowry: The Ideology of Early Kádárism]. Budapest: Magvető, 1998. 
Kedves, jó Kádár elvtárs! Válogatás Kádár János levelezéséből 1954-1989 [Dear Good Comrade Kádár: Selected Correspondence of János Kádár 1954-1989]. Edited by Tibor Huszár. Budapest: Osiris, 2002.

Zoltán Kodály, Visszatekintés [Looking Back], 3 vols. Edited by Ferenc Bónis. Budapest: Zeneműkiadó, 1982, 1989.

Zoltán Kodály, Writings on Music Education. Edited by Mihály Itzzés, transl. Kata Ittzés. Budapest: Liszt Academy, 2019.

György Kroó, A magyar zeneszerzés harminc éve [30 years of Hungarian music]. Budapest: Zeneműkiadó, 1975.

Nylon Curtain: Transnational and Transsystemic Tendencies in the Cultural Life of State-Socialist Russia and East-Central Europe. Edited by György Péteri (Trondheim: Program on East European Cultures and Societies, 2006), quotation from György Péteri: "Introduction." Andrey Olkhovsky, Music under the Soviets: The Agony of an Art. New York: Praeger, 1955.

György Péteri, “Purge and Patronage: Kádár's Counter-Revolution and the Field of Economic Research in Hungary, 1957-1958." Contemporary European History, 11/1 (February 2002). Lóránt Péteri, "God and Revolution - Rewriting the Absolute: Bence Szabolcsi and the Discourse of Hungarian Musical Life." In Music's Intellectual History. Edited by Zdravko Blažeković, Barbara Dobbs Mackenzie (New York: Répertoire International de Littérature Musicale, 2009). RILM Perspectives 1.

Lóránt Péteri, “'Soviet Music' in Hungary: Ilya Golovin Reaches Budapest.” In Socialist Realism and Music. Edited by Mikulaš Bek, Geoffrey Chew, Petr Macek. Prague: KLP - Koniasch Latin Press, 2004.

Lóránt Péteri, “The 'Question of Nationalism' in Hungarian Musicology during the State Socialist Period." In Nationality vs Universality: Music Historiographies in Central and Eastern Europe. Edited by Sławomira Żerańska-Kominek. Newcastle upon Tyne: Cambridge Scholars Publishing, 2016.

János Rainer M., Bevezetés a kádárizmusba [An Introduction to Kádárism]. Budapest: 1956-os Intézet and L'Harmattan, 2011.

Ignác Romsics, A 20. század rövid története [A Brief History of the $20^{\text {th }}$ Century]. Budapest: Rubicon, 2011.

Ignác Romsics, Magyarország története a XX. században [The $2 \mathrm{O}^{\text {th }}$-Century History of Hungary]. Budapest: Osiris, 1999.

Éva Standeisky, Az irók és a hatalom, 1956-1963 [Writers and the Political Power]. Budapest: 1956-os Intézet, 1996. 
Adrian Thomas, Polish Music since Szymanowski. Cambridge: Cambridge University Press, 2005.

Tibor Tallián, Magyarországi hangversenyélet 1945-1958 [Concert Culture in Hungary]. Budapest: MTA Zenetudományi Intézet, 1991.

Tibor Tallián, Magyar képek: Fejezetek a magyar zeneélet és zeneszerzés történetéböl, 1940-1956 [Hungarian Pictures: Chapters of Hungarian Music Culture and Musical Composition, 1940-1956]. Budapest: Balassi Kiadó, MTA Bölcsészettudományi Kutatóközpont, changed edition, 2014 .

Kiril Tomoff, “'Most Respected Comrade...': Patrons, Clients, Brokers and Unofficial Networks in the Stalinist Music World." Contemporary European History, 11/1 (February 2002). Andrey Aleksandrovich Zsdánov [Zhdanov], A müvészet és filozófia kérdéseiröl [On Questions of Art and Philosophy]. Budapest: Szikra, 1949.

BIOGRAM

Lóránt Péteri - Professor and head of the Musicology Department of the Liszt Academy of Music, Budapest. He has been also lecturing at the Aquincum Institute of Technology, Budapest since 2011. He is a member of the Advisory Board of the Gustav Mahler Research Centre (Toblach), of the Council of the Hungarian Musicological Society, and of the Musicological Committee of the Hungarian Academy of Sciences. He has given papers about the music culture of state socialist Hungary and about the music of Gustav Mahler in international conferences (in Bristol, Brno, Budapest, Canterbury, Cardiff, Dobbiaco, Guildford, New York, Pittsburgh, Radziejowice, and Wrocław). He has been a regular guest at Radio Bartók for the last two decades. Among his latest contributions is his chapter in The Routledge Handbook of Music Signification, eds. Esti Sheinberg and William P. Dougherty (2020).

\section{BIOGRAM}

Lóránt Péteri - Profesor i dyrektor Wydziału Muzykologii na Uniwersytecie Muzycznym im. Ferenca Liszta w Budapeszcie, a także (od 2011) wykładowca w budapeszteńskim Aquincum Institute of Technology. Jest członkiem rady konsultacyjnej przy Centrum Badań im. Gustava Mahlera w Toblach, zarządu Węgierskiego Towarzystwa Muzykologicznego oraz Komitetu Muzykologicznego przy Węgierskiej Akademii Nauk. Jego artykuły nt. kultury muzycznej komunistycznych Węgier i muzyki Gustava Mahlera były prezentowane podczas międzynarodowych konferencji w Bristolu, Brnie, Budapeszcie, Canterbury, Cardiff, Dobbiaco, Guildford, Nowym Jorku, Pittsburghu, Radziejowicach i Wrocławiu.

Od ok. 20 lat występuje regularnie na antenie Radia Bartók. Ostatnio napisał też rozdział do The Routledge Handbook of Music Signification, red. Esti Sheinberg, William P. Dougherty (2020). 
ABSTRACT

National Icon and Cultural Ambassador: Zoltán Kodály in the Musical Life of State Socialist Hungary

In my paper, I wish to raise questions pertinent to the changing position of the composer, ethnomusicologist and musical educationalist Zoltán Kodály in the musical and cultural life of the Stalinist and post-Stalinist periods of Hungarian state socialism. Owing to his folkloristic and conservative musical style, and also his identity as "an educator of the people," Kodály established his status as a fellow traveller of state socialism in the early 1950s. The easiest way in Hungarian composition to satisfy the expectations of the political power, as inspired by Zhdanov's aesthetics, was to follow the style of Kodály. At the same time, Kodály sustained his reputation as a "genuine" national icon whose music was capable of expressing, even if in riddle form, anti-Stalinist sentiments in the eyes of various political and cultural circles, especially after 1953 . In spite of the fact that Kodály did not take any active part in the political struggles in the revolution of 1956 , he was named as a candidate for head of state by important revolutionary forces.

Following the suppression of the revolution, the restored state socialist political power revised its practices in the field of art. The fact that the new cultural policy gave up the idea of a unified Hungarian art which is "national in form and socialist in content," resulted in a temporary weakening of Kodály's position. Kodály's status was precarious, subjected to a challenge by avant-garde trends in

\section{STRESZCZENIE}

Ikona narodowa i ambasador kultury wegierskiej: Zoltán Kodály wżyciu muzycznym komunistycznych Wegier

W moim artykule podnoszę temat zmieniającej się pozycji kompozytora, etnomuzykologa i edukatora muzycznego Zoltána Kodálya w życiu muzycznym i kulturalnym komunistycznego państwa węgierskiego w okresie stalinizmu i latach, które nastąpiły po nim. Dzięki swojemu konserwatywnemu, inspirowanemu folklorem, językowi muzycznemu, a także sławie „nauczyciela narodu”, Kodály zyskał we wczesnych latach 50. Xx wieku status niezrzeszonego sympatyka i sojusznika aparatu socjalistycznego państwa. Najłatwiejszym sposobem zaspokojenia inspirowanych manifestami estetycznymi Żdanowa oczekiwań władzy politycznej w dziedzinie komponowania muzyki było naśladownictwo stylu Kodálya. Jednocześnie artysta ten zachował reputację „prawdziwej” ikony narodu węgierskiego. W opinii wielu kręgów politycznych i kulturalnych, jego muzyka była w stanie wyrażać (choć w zawoalowany sposób) nastroje antystalinowskie - szczególnie po 1953 roku. Choć Kodály nie brał aktywnego udziału w walce politycznej związanej z rewolucją węgierską roku 1956, był wymieniany jako kandydat na głowę państwa przez ważne siły rewolucyjne.

Po stłumieniu powstania, przywróceni do władzy komuniści skorygowali swoją politykę wobec sztuki. Nowa polityka kulturalna rezygnowała z koncepcji zunifikowanej sztuki węgierskiej, która byłaby „narodowa w formie i socjalistyczna w treści”. Poskutkowało to chwilowym osłabieniem 
composition and competing paradigms of musical education. From the early 1960 s, however, when both the Western and Eastern political systems proposed strategies for long-term coexistence, Kodály gained a new function from the perspective of the political power. In Western cultural circles Kodály sustained a reputation as one of the great European humanists, and his music educational method generated a strong professional interest globally, and particularly in the USA. My paper also examines the cultural political impact of Kodály's visit to Moscow in 1963. Kodály seems to have functioned as a mediator across the political divide. He had achieved great personal successes during his tours to the political West, and this reinforced his position in Hungary.

KEYWor ds Zoltán Kodály, Stalinism, 1956 revolution, Post-Stalinism, Kodály method pozycji Kodálya, która stała się niepewna, szczególnie wobec wyzwań, jakie niosły ze sobą awangardowe nurty kompozytorskie oraz konkurencyjne modele edukacji muzycznej. Jednakże począwszy od wczesnych lat 6o., kiedy zarówno blok wschodni, jak i zachodni wystąpiły ze strategiami długoterminowego współistnienia, Kodály zyskał w oczach władzy nową funkcję, związaną $\mathrm{z}$ jego reputacją $\mathrm{w}$ kręgach kulturowych Zachodu jako jednego z wielkich humanistów europejskich, a także autora metody edukacyjnej, która cieszyła się wielkim zainteresowaniem profesjonalistów na całym świecie, szczególnie w Stanach Zjednoczonych. W moim artykule analizuję również polityczne efekty wizyty Kodálya w Moskwie w 1963 roku. Wydaje się, że kompozytor pełnił wówczas rolę mediatora ponad podziałami politycznymi. Jego podróże na Zachód przyniosły mu wielkie sukcesy osobiste, co umocniło jego pozycję na Węgrzech.

Stowa kLuczowe Zoltán Kodály, stalinizm, rewolucja 1956 roku, okres postalinowski, metoda Kodálya 